\title{
Comparative analysis and long-term dynamics of soil macrofauna in forest-tundra ecotone of the Khibiny mountains
}

\author{
Сравнительный анализ и многолетняя Аинамика населения \\ почвенной мезофауны в экотоне лес-тундра \\ Хибинского горного массива
}

\author{
L.B. Rybalov, I.O. Kamayev \\ А.Б. Рыбалов, И.О.Камаев
}

Institute of Ecology and Evolution, Russian Academy of Science, Leninsky Prospect 33, Moscow 119071, Russia.

Институт по проблемам экологии и эволюции РАН, Ленинский проспект 33, Москва 119071, Россия.

KEY WORS: soil macrofauna, forest-tundra ecotone, north taiga, The Khibiny mountains.

КЛЮЧЕВЫЕ СЛОВА: почвенная мезофауна, экотон лес-тундра, северная тайга, Хибины.

ABSTRACT. Clear soil macrofauna dynamics in forest-tundra ecotones of the Khibiny mountains haven't been found over 23 year's period. But abundance of macrofauna in two forest types significantly increased in 2009-2010 when compared to 1986. There are three types of macrofauna complexes: forest with higher earthworms densities, tundric with macrofauna of low diversity and high abundance, and ecotone. Increasing densities and numbers of all macrofauna and dominant taxa weren't recorded in forest-tundra ecotone. Green moss covering determines the affinity of macrofauna in both spruce forest and tundra. For north foresttundra ecotone the distribution of earthworms depends on winter minimal temperature of soil.

РЕЗЮМЕ. Выраженная динамика населения почвенной мезофауны в экотоне лес-тундра Хибинского горного массива за 23-летний период выявлена не была. Однако численность мезофауны значимо возросла в 2009-2010 гг. по сравнению с 1986 г. в двух типах лесов. Выделено три комплекса почвенной мезофауны: «лесной» с высокой плотностью дождевых червей, «тундровый» с низким разнообразием и обилием мезофауны и «экотонный». В экотоне лес-тундра не отмечено резкое увеличение показателей обилия и разнообразия таксонов мезофауны по сравнению с соседними сообществами. Напочвенный покров из зеленых мхов во многом определяет сходство населения мезофауны тундры и ельника Хибин. Выявлено, что распределение дождевых червей в экотоне лес-тундра Хибин зависит от минимальных зимних температур.

\section{Introduction}

Climate-induced tree line advances have been reported for some mountain regions: Alaska, Yukon, Urals, Fennoscandia [Moiseev, Shiyatov, 2003; Lloyd,
2005; Danby, Hik, 2007; Kammer et al., 2009]. At the same time the climate changes have also been observed in the Khibiny mountains [Demin, Zjuzin, 2006]: increasing temperature and thickness of snow cover. As a result ecosystems and its compounds will bear changes in mountain communities' forest-tundra ecotones. Soil macrofauna, an important group in soil-forming, was diverse and numerous that is not common for subarctic ecosystems under severe climatic conditions. It's interesting how soil macroinvertebrates will response on these changes.

The Khibiny mountain's ecosystems differ from plain zonal communities by their unique conditions. First, it places on rich soil-forming rocks with predominance of eluvial-delluvial nepheline syenite. The Khibiny mountain's ecosystems are characterized by specifics microclimate with higher amounts of precipitation, complex relief, higher plant species diversity with large share of herbaceous in forest communities. All highaltitude zones including forest-tundra ecotones and main forest types that are typical for the Khibiny mountains are present in the Vudjavrchorr mountain. This is why, we have selected it as a model area for soil zoology investigations. Several types of ecosystems ( 2 tundra, 3 forests and forest-tundra) of this territory were studied at the end of 1980-s earlier [Rybalov, Rossolimo, 1994]. We continued this study on the same plots in 2009-2010.

The goal of our work was to study soil macrofauna dynamics over 23 year's period in the forest-tundra ecotone of the Khibiny mountains.

\section{Materials and methods}

The north-eastern slope of the Vudjavrchorr mountain located in the Khibiny mountains, in the central part of Kola Peninsula $\left(67^{\circ} 38^{\prime}\right.$ N, $33^{\circ} 39^{\prime}$ E) has been chosen as the study area. This territory is characterized 
Table 1. The characteristics of forest-tundra ecotone's ecosystems. Табл. 1. Характеристика исследуемых сообществ экотона лес-тундра.

\begin{tabular}{|c|c|c|c|}
\hline $\begin{array}{c}\text { Community } \\
\text { type }\end{array}$ & Site type & Altitude, m & Dominant plant species \\
\hline \multirow[t]{2}{*}{ Tundra } & Lichen tundra (TL) & 550 & $\begin{array}{l}\text { Betula nana L., Cetraria islandica L., } \\
\text { Cetraria nivalis (L.) Ach., Cladonia alpina } \\
\text { (Schaer.) }\end{array}$ \\
\hline & $\begin{array}{l}\text { Tundra with green moss and } \\
\text { schrubs (TM) }\end{array}$ & 500 & $\begin{array}{l}\text { Betula nana L., Vaccinium vitis-idaea L., } \\
\text { Vaccinium myrtilis L., Empetrum herma- } \\
\text { phroditum Hagerup, Pleurozium schreberi, } \\
\text { Dicranum sp. }\end{array}$ \\
\hline Forest-tundra & Birch alpine forest (FT) & 370 & $\begin{array}{l}\text { Betula pubescens Ehrh., Empetrum herma- } \\
\text { phroditum Hagerup, Salix sp., Pleurozium } \\
\text { schreberi, Dicranum sp. }\end{array}$ \\
\hline \multirow[t]{3}{*}{ Forest } & $\begin{array}{l}\text { Birch forest with Sorbus and } \\
\text { Geranium (BG) }\end{array}$ & 360 & $\begin{array}{l}\text { Betula pubescens Ehrh., Sorbus gorodkovii } \\
\text { Pojark., Geranium sylvaticum L., Gymno- } \\
\text { carpium dryopteris (L.) Newm. }\end{array}$ \\
\hline & $\begin{array}{l}\text { Spruce forest with birch, } \\
\text { schrubs and Geranium (SF) }\end{array}$ & 350 & $\begin{array}{l}\text { Picea abies (L.) Karst., Deschampsia } \\
\text { caespitosa (L.) Beauv., Geranium sylvaticum } \\
\text { L., Vaccinium vitis-idaea L., Vaccinium } \\
\text { myrtilis } \text { L., Hylocomium splendens, } \\
\text { Pleurozium schreberi, Dicranum sp. }\end{array}$ \\
\hline & $\begin{array}{l}\text { Birch forest with Cicerbita and } \\
\text { Calamogrostis (BP) }\end{array}$ & 320 & $\begin{array}{l}\text { Betula pubescens Ehrh., Chamaeperi- } \\
\text { clymenum suecicum (L.) Asch.\&Graebn., } \\
\text { Calamogrostis sp., Geranium sylvaticum L., } \\
\text { Gymnocarpium dryopteris (L.) Newm. }\end{array}$ \\
\hline
\end{tabular}

by mild climate with high amount of precipitation and mild winter due to influence of the Gulf Stream. We have investigated 2 tundric, 1 forest-tundric and 3 forest communities that are situated in northern taiga (Table 1).

Soil macrofauna was collected with hand-sorting of soil samples $(25 \times 25 \mathrm{~cm})$ in August of 1986 and 2009 2010. 8 or 16 soil samples per plot have been taken. Sand-sorting of samples was made taking into consideration the structure of soil profile. Then samples with organic layers were put in plastic bag and further sorted in laboratory. Mineral soil samples were sorted directly on-site. Density was determined in examples per square meter $\left(\mathrm{ex} . / \mathrm{m}^{2}\right)$. The fauna of soil invertebrates including the herpetobios was estimated using pitfall traps and sifting. Larvae of insects, spiders and Staphylinidae were fixed in $70 \%$ ethanol and earthworms were put in $4 \%$ formalin.

The temperature of soil organic layers was determined with thermometers (TM-1\&TM-2) in 1986 and data-loggers in 2009 in the course of year.

The mathematics analysis was made using software of Statistica 6.0 and PAST 2.11.

\section{Results}

Taxonomic diversity of soil macrofauna

The lower number of taxa is observed in the lichen tundra and the higher number - in the spruce forest. The comparative analysis of soil macrofauna diversity showed that mean number of above species taxa was 25 in 1986 and 24 in 2009-2010 (Table 2).
We found 88 species of Aranei, 50 species of Staphylinidae, 4 species of Lumbricidae, 10 species of Mollusca, 11 species of Carabidae and others in the communities of the Vudjavrchorr mountain (Table 3). Also some species are known from literature [Zenkova et al., 2011]. Thus macrofauna of this area numbers over 170 species; the most part of them is wide-spread boreal.

Table 2. Number taxa of soil macrofauna in forest-tundra ecotone on 2 period of investigations.

Табл. 2. Число таксонов почвенной мезофауны в экотоне лес-тундра за два периода исследований.

\begin{tabular}{|l|c|c|c|c|c|c|}
\hline \multirow{2}{*}{ Year } & \multicolumn{6}{|c|}{ Site type } \\
\cline { 2 - 7 } & \multicolumn{2}{|c|}{ Tundra } & Ecotone & \multicolumn{3}{|c|}{ Forests } \\
\cline { 2 - 7 } & TL & TM & FT & BG & SF & BP \\
\hline 1986 & 10 & 15 & 15 & 15 & 16 & 13 \\
\hline $\begin{array}{l}2009- \\
2010\end{array}$ & 9 & 14 & 13 & 13 & 16 & 14 \\
\hline
\end{tabular}

Table 3. Number species of numerous macrofauna taxa. Табл. 3. Число видов массовых таксонов мезофауны.

\begin{tabular}{|l|c|c|c|c|}
\hline \multicolumn{1}{|c|}{ Taxon } & 1986 & $\begin{array}{c}2009- \\
2010\end{array}$ & $\begin{array}{c}\text { All in both } \\
\text { periods }\end{array}$ & $\begin{array}{c}\text { Literature } \\
\text { data* }^{*}\end{array}$ \\
\hline Mollusca & 5 & 10 & 10 & 4 \\
\hline Lumbricidae & 4 & 4 & 4 & 6 \\
\hline Aranei & 52 & 70 & $88^{* *}$ & - \\
\hline Staphylinidae & 44 & 38 & 50 & 47 \\
\hline Carabidae & 13 & 11 & 13 & 22 \\
\hline $\begin{array}{l}\text { Other } \\
\text { Coleoptera }\end{array}$ & - & 9 & 9 & 10 \\
\hline
\end{tabular}

* - Zenkova et al., 2011; ** — data, including materials Tanasevitch and Kamayev, 2011. 


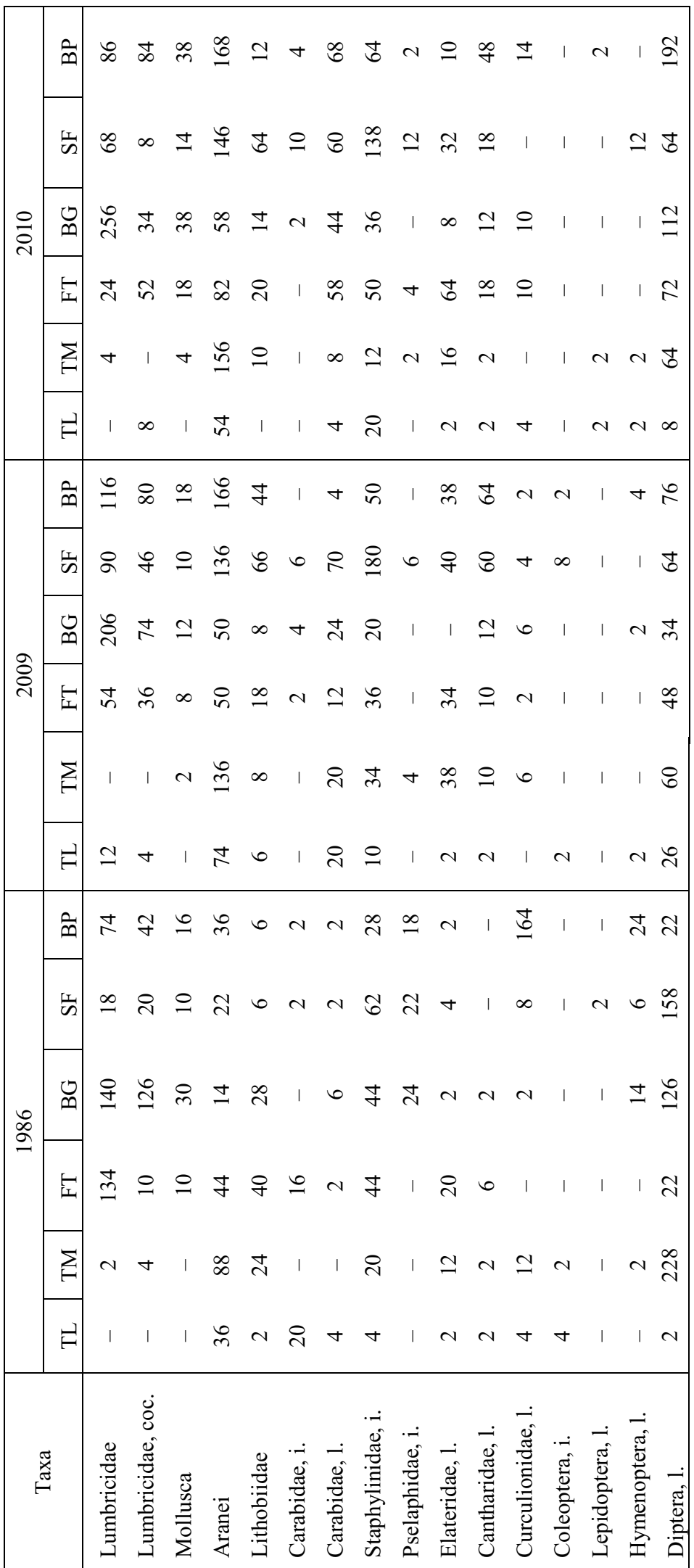

In forest-tundra ecotone number of macrofauna taxa wasn't different in both periods of investigations and wasn't higher as compared with tundra with green moss and birch forest with Geranium. It means that edge effect for taxonomic diversity of soil macrofauna wasn't observed in forest-tundra ecotone of the Vudjavrchorr mountain.

Density of soil macrofauna

The total density of macrofauna sequentially increased from lichen tundra to forests (Fig. 1). This parameter ranged from 82 to $482 \mathrm{ex} . / \mathrm{m}^{2}$ in 1986 and from 104 to $798 \mathrm{ex} . / \mathrm{m}^{2}$ in $2009-2010$. Total density is significantly higher in forest ecosystems excluding forest-tundra and birch forest with Geranium in 20092010 than 1986. However differences of macrofauna abundances are not significant in 2 tundric and forest-tundra communities. We suppose that increasing of total density may be associated with growth of snow cover thickness over 20 year's period in mountain valley.

\section{Structure of soil macro- fauna \\ Composition of soil macro-} fauna depends on community type (Table 4). The tundric ecosystems are characterized by lower abundances of macrofauna taxa excluding spiders (Aranei). For example, density of earthworms varies from 2 to $12 \mathrm{ex}$./ $\mathrm{m}^{2}$. In 1986 we observed higher abundance of dipteras larvae presented by Bibionidae (214 ex./ $\mathrm{m}^{2}$ ). Maybe it was determined by waves of life of these insects [Chetverikov, 1905].

In forest types of ecosystems earthworms were numerous; their density varied from 68 to 256 $\mathrm{ex} . / \mathrm{m}^{2}$. The higher abundance of Staphylinidae was recorded only in spruce forest $\left(62-180 \mathrm{ex} . / \mathrm{m}^{2}\right)$.

The forest-tundra ecotone is characterized by two complexes of macrofauna taxa. One of them habitats forest ecosystems and other complex is tundric. So in 
Table 5. Species diversity and distribution of earthworms. Табл. 5. Видовое разнообразие и распределение дождевых червей.

\begin{tabular}{|l|c|c|c|c|c|c|}
\hline \multicolumn{1}{|c|}{ Species } & TL & TM & FT & BG & SF & BP \\
\hline Aporrectodea caliginosa (Savigny, 1826) & - & - & + & + & + & + \\
Dendrobaena octaedra (Savigny, 1826) & + & + & + & - & + & + \\
Dendrodrilus rubidus (Eisen, 1874) & - & - & + & - & + & + \\
Lumbricus rubellus Hoffmeister, 1843 & - & - & + & + & + & + \\
\hline $\mathrm{Tw}_{\min },{ }^{\circ} \mathrm{C}$ & d.a. & $-2,3$ & $-0,5$ & $-0,1$ & $-0,1$ & d.a. \\
\hline
\end{tabular}

$\mathrm{Tw}_{\min }$ - minimal winter temperature in soil, d.a. — data absence.

forest-tundra ecotone earthworms are abundant the same way as in forest ecosystems, but as a rule density of the others macrofauna taxa is comparable with the one of tundric communities.

Distribution of spiders in mountain ecosystems depends on green moss covering and moor humus in the first place. Density of spiders was higher in spruce and birch forests and tundra with green moss and powerful litter (136-168 ex. $/ \mathrm{m}^{2}$ in 2009-2010) and this parameter was lower in birch forests without litter and green mosses.

Comparison of soil macrofauna densities over 23 years' period showed that abundance of earthworms as well as spiders increased in all types of the mountain ecosystems excluding forest-tundra ecotone. The most unstable density was recorded for dipterous larvae in tundric and some forest communities. Alike in 1986 the density of Curculionidae was $164 \mathrm{ex} . / \mathrm{m}^{2}$ in birch forest (BP) but in 2009-2010 this parameter varied from 2 to $14 \mathrm{ex} . / \mathrm{m}^{2}$.

\section{dient}

Distribution of earthworms in high-altitude gra-

We found 4 species of earthworms, which were recorded in forest types of ecosystems excluding birch

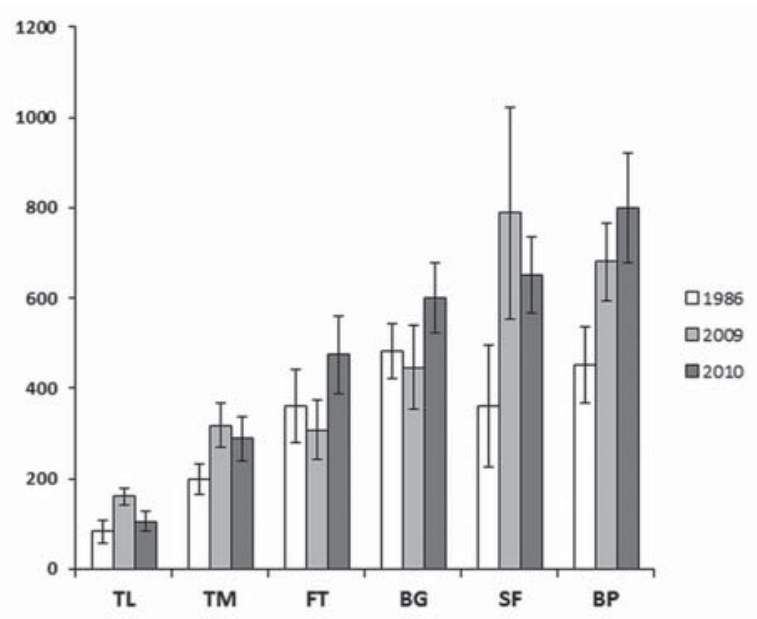

Fig. 1. Density of soil macrofauna $\left(\mathrm{ex} . / \mathrm{m}^{2}\right)$ in communities of the Khibiny mountains.

Рис. 1. Численность почвенной мезофауны (экз./м²) в сообществах Хибинского горного массива. forest with geranium (Table 5). In tundric communities only one specie (Dendrobaena octaedra) was observed in both periods of investigations.

We explain differences in abundance and diversity of the earthworms by influence of minimal winter temperatures. Earlier the freeze-resistance of earthworms was investigated by Mecheryakova [2011]. It have been shown that Dendrodrilus rubidus and Lumbricus rubellus don't survive at a temperature below $2-3^{\circ} \mathrm{C}$. The mean of crucial temperature for Dendrobaena octaedra is $15^{\circ} \mathrm{C}$. Our data of earthworms' diversity and distribution conform to distribution of winter minimal temperature in soil (Table 5).

\section{Conclusion}

We didn't find clear differences of soil macrofauna communities in forest-tundra ecotones of the Khibiny mountains over 23 year's period. But abundance of macrofauna significantly increased in 2009-2010 in two forest types due to growth of earthworms' density. Distribution of earthworms depends on winter minimal temperature in soil of north forest-tundra ecotone.

Main types of macrofauna complex were marked out. Tundric communities are characterized by low densities of macrofauna with dominance of litter complex invertebrates. On the contrary higher densities of macrofauna were observed in mountain forests where soil-litter earthworms were numerous in comparison with typical north taiga forests. Thus soil-litter complex inhabits the forest soils. Forest-tundra combine both complexes of macrofauna and is transition (ecotone) without edge effect (increasing densities and numbers of all macrofauna and dominant taxa).

We suppose that green moss cover is one of the important factors of macrofauna differentiation. In particular soil-habitated spiders are numerous in communities with green moss cover, for example, tundra and spruce forest. This factor also determines macrofauna likeness both in spruce forest and tundra, especially, on micromosaic level of biogeocenosis.

ACKNOWLEDGMENTS. The authors are grateful to Prof. N.V. Lukina and T.E. Rossolimo for cooperation and discussion of this work, to V.B. Semenov for identification of Staphylinidae and some Co- 
leopteras, to I.G. Vorobjeva, A.O. Svinin and V.D. Leonov for their help in collecting of material. This work is particularly supported by Young Scientist Support Grant of President of the Russian Federation (MK4046.2011.4) and project 10-04-00213-a of the Russian Foundation for Basic Research.

\section{References}

Demin V.I., Zyuzin Yu.L. 2006. On climatic changes in the Khibiny Mountains (Kola Peninsula, Russia) // «Physics of Auroral Phenomena», Proc. XXIX Annual Seminar. Apatity, 2006. P.281-284.

Rybalov L., Rossolimo T. 1994. Landscape and altitude distribution of subarctic region invertebrates // International Confer- ence on Northern Wilderness Areas: Ecology, Sustainability, Values. Rovaniemi, Finland. P.40.

Zenkova I.V., Pozharskaya V.V., Pokhil'ko A.A. 2011. Altitudinal Distribution of Soil Fauna in the Khibiny Massif // Eurasian Soil Science. Vol.49. No.9. P.991-1000.

Mecheryakova E.N. 2011. Ustoichivost dozchdevych cherveij (Oligochaeta, Lumbricidae, Moniligastridae) k otricatelnym temperaturam. Avtoref. ... diss. kand. biol. nauk. SPb. 18 p. [in Russian].

Tanasevitch A.V., Kamayev I.O. 2011. [Spiders of Kola Peninsula, Russia (Arachnida: Aranei)] // Caucasian entomological bulletin. Vol.7. No.1. P.7-32 [in Russian with English summary].

Chetverikov S.S. 1905. [Waves of life (from lepidopterological observation in summer 1903)] // Dnevnik Zool. otdeleniya imper. Obshchestva lyubitelei estestvoznaniya, antropologii i etnographii. T.3. No.6. P.106-111 [in Russian]. 